\title{
GENDER FEATURES OF THE PHYSICAL STATE OF MEDICAL UNIVERSITY PROFESSORS OF PRE-RETIREMENT AND RETIREMENT AGE
}

\author{
Latyshevskaya $\mathrm{NI}^{1,2}$, Belyaeva $\mathrm{AV}^{1,2}$, Kovaleva MD¹, Levchenko NV ${ }^{1}$
}

${ }^{1}$ Volgograd State Medical University, Volgograd, Russia

${ }^{2}$ Volgograd Medical Research Center, Volgograd, Russia

\begin{abstract}
In the past few years, the number of elderly people has been growing in Russia. Every fifth retired person does not resign and continues to work. The situation with employees that have already reached the retirement age is distinctly special in the country's higher education establishments. Therefore, the task of studying the peculiarities of health of higher school professors that have already passed the retirement age threshold or are approaching it is an urgent one, the purpose of such a study being prolongation of the "healthy old age". It is necessary to factor in gender specifics, since, according to the statistics, men run greater risks of developing chronic non-communicable diseases than women. The purpose of this study was to investigate the gender-related peculiarities of the physical condition and the rate of aging of medical university professors of pre-retirement and retirement age with the aim to develop measures enabling such employees to maintain a high level of working efficiency. The study involved 169 teachers aged 55-70. A set of anthropometric measurements was taken. The participants had their blood pressure measured, level of physical condition and their adaptive potential assessed. The rate of aging and biological age were calculated for all the participants with the help of A.G. Gorelkin and B.B. Pinkhasov's formulas. The study revealed significant differences in most morpho-functional status indicators signaling of the greater cardiovascular system disease risks run by male teachers compared with their female peers. However, female participants presented significantly more cases of obesity, which explains the revealed differences in the rate of aging that was higher among women.
\end{abstract}

Key words: physical state, retirement age, university teachers, gender characteristics.

Author contribution: Latyshevskaya $\mathrm{NI}$ - literature analysis, research planning, data interpretation, manuscript drafting; Belyaeva AV — literature analysis, research planning, data collection, data analysis, data interpretation, manuscript drafting; Kovaleva MD — research planning, data collection; Levchenko NV — data collection, data analysis, data interpretation.

Compliance with ethical standards: All the participating professors enrolled voluntarily and signed an informed consent before being included in the study.

$\triangle$ Correspondence should be addressed: Alina Vasilievna Belyaeva

pl. Pavshykh Bortsov, 1, Volgograd, 400131, Russia; bel.alina@list.ru

Received: 20.04.202 Accepted: 15.05.2021 Published online: 25.06.2021

DOI: $10.24075 /$ rbh.2021.012

\section{ГЕНДЕРНЫЕ ОСОБЕННОСТИ ФИЗИЧЕСКОГО СОСТОЯНИЯ ПРЕПОДАВАТЕЛЕЙ МЕДИЦИНСКОГО ВУЗА ПРЕДПЕНСИОННОГО И ПЕНСИОННОГО ВОЗРАСТА}

\author{
Н. И. Латышевская ${ }^{1,2}$, А. В. Беляева ${ }^{1,2}$, М. Д. Ковалева ${ }^{1}$, Н. В. Левченко \\ Волгоградский государственный медицинский университет, г. Волгоград, Россия \\ ${ }^{2}$ Волгоградский медицинский научный центр, г. Волгоград, Россия
}

\begin{abstract}
В последние годы в России наблюдается рост числа лиц пожилого возраста. Каждый пятый пенсионер продолжает работать. Особая ситуация с работающими пенсионерами в вузах страны. В связи с этим актуальна задача изучения особенностей здоровья преподавателей предпенсионного и пенсионного возраста с целью продления «здоровой старости». Необходимо учитывать и гендерные различия, так как согласно статистике среди мужчин распространенность факторов риска развития хронических неинфекционных заболеваний выше, чем среди женщин. Цель исследования: изучить гендерные особенности физического состояния и коэффициента скорости старения преподавателей предпенсионного и пенсионного возраста медицинского вуза для разработки мероприятий по сохранению высокого уровня работоспособности данного контингента работающих. В исследовании приняли участие 169 преподавателей 55-70 лет. Осуществлен комплекс антропометрических измерений. Проведены измерение артериального давления, оценка уровня физического состояния обследуемых и адаптационного потенциала. Для всех участников рассчитаны коэффициент скорости старения и биологический возраст по формулам А.Г. Горелкина и Б.Б. Пинхасова. В результате исследования выявлены достоверные различия по большинству показателей морфо-функционального статуса, представляющих риск развития заболеваний сердечнососудистой системы у преподавателей мужского пола по сравнению с женщинами. Однако среди преподавателей женского пола выявлено достоверно больше случаев ожирения, что объясняет выявленные различия по коэффициенту скорости старения, который оказался выше среди женщин.
\end{abstract}

Ключевые слова: физическое состояние, пенсионный возраст, преподаватели вуза, гендерные особенности.

Key words: physical state, retirement age, university teachers, gender characteristics.

Вклад авторов: Латышевская Н.И.- анализ литературы, планирование исследования, интерпретация данных, подготовка черновика рукописи; Беляева А.В.- анализ литературы, планирование исследования, сбор данных, анализ данных, интерпретация данных, подготовка черновика рукописи; Ковалева М.Д.- планирование исследования, сбор данных; Левченко Н.В.—сбор данных, анализ данных, интерпретация данных.

Соблюдение этических стандартов: Участие преподавателей было добровольным, все обследуемые подписали информированное согласие перед включением в исследование.

$\bowtie$ Для корреспонденции: Алина Васильевна Беляева

пл. Павших Борцов, д. 1, г. Волгоград, 400131, Россия; bel.alina@list.ru

Поступила: 20.04.202 Статья принята к печати: 15.05.2021 Опубликована онлайн: 25.06.2021

DOI: 10.24075/rbh.2021.012 
Today, the older generation is the most rapidly growing population in the world. With the life expectancy in the Russian Federation increasing, the process of demographic aging has accelerated, i.e. the share of elderly and old people in the country's population grows larger every year. There economic, social and political aspects to this problem. It is one of the global challenges of our time [1].

At the same time, according to a number of foreign and Russian authors, elderly people represent a significant labor resource [2]. Today, every fifth retired person in Russia continues to work. The situation with employees that have already reached the retirement age is distinctly special in the country's higher education establishments. There, over the past two decades, the share of young professors (up to 30 years old) has increased from 9.6 to $14.4 \%$, the groups of professors aged 30 to 39 and 40 to 49 have shrunk from $32-33 \%$ to $18-20 \%$, and the group of those 50 to 59 years old remained stable (18.1-20.2\%). The largest group is that which includes professors aged 60 and older (27.7\%). The most dynamic age group is comprised of people over 65: over a decade and a half, their share has increased 2.6 times [2]. The more extended the job description and the list of qualifications, the older (on average) the members of the social and professional group (doctors of sciences, academics). The work of higher school professors is associated with a high level of responsibility, large volumes and unevenness of incoming information, physical inactivity, often - irrational organization [3, 4].

The increase of the retirement age added urgency to the matter of development of a system of measures to preserve and strengthen the professional health of workers as a factor in ensuring their professional longevity.

According to the statistics, men run greater risks of developing chronic non-communicable diseases than women. Moreover, compared to Russian women, Russian men have a greater disease burden, and this discrepancy is the most pronounced in the world $[1,5,6]$.

Therefore, the task of studying the peculiarities of health of higher school professors that have already passed the retirement age threshold or are approaching seems to be an urgent one, the purpose of such a study being prolongation of the "healthy old age".

\section{PURPOSE OF THE STUDY}

Investigate the gender-related peculiarities of the physical condition and the rate of aging of medical university professors of pre-retirement and retirement age with the aim to develop measures enabling such employees to maintain a high level of working efficiency.

\section{MATERIALS AND METHODS}

The study involved 169 professors from theoretical departments of the Volgograd State Medical University (87 women and 82 men), aged 55 to 70 , all having the same teaching load. All the participants enrolled voluntarily and signed the informed consent before being included in the study.

A set of anthropometric measurements was taken. The participants' height was measured without shoes and outerwear, with the help of the height meter (accuracy of 1 $\mathrm{cm}$ ); body weight (BW) measurements relied on the medical floor scales (accuracy of $100 \mathrm{~g}$ ). Waist circumference (WC) was measured with a centimeter tape (accuracy of $0.5 \mathrm{~cm}$ ) when the participants were standing, midway between the edge of the costal arch and the edge of the iliac crest on both sides of the lateral surface of the trunk. The BW was evaluated in the categories of the Quetelet index (BMl — body weight (kg) / height (m) 2). According to the WHO classification (1997, 2003), in the context of BMI, BW can be insufficient (BMl<18.5), normal (18.5 $\leq \mathrm{BMl} \leq 24.9$ ), excessive (25.0 $\leq \mathrm{BMI} \leq 29.9$ ), and there are three degrees of obesity: I degree (30.0 $\leq \mathrm{BMI} \leq 34.9)$, II degree $(35.0 \leq \mathrm{BMl} \leq 39.9)$ and III degree $(\mathrm{BMl}>40)$. As for the abdominal obesity $(\mathrm{AO})$ it was registered based on the WC values, $\geq 94 \mathrm{~cm}$ and $\geq 80 \mathrm{~cm}$ for male and female participants, respectively [7].

Blood pressure (BP) was measured twice, on the right arm, with the participant sitting, using an automatic tonometer. The average BP was calculated from the two measurements. Those with BP above 140/90 mm Hg and/ or taking antihypertensive drugs (AHD) constituted the arterial hypertension $(\mathrm{AH})$ group [6]. We assessed the physical condition $(\mathrm{PC})$ of the participants, which reflects the degree of resistance of their bodies to adverse external factors, and their adaptive potential (AP), which shows the intensity of the adaptive reactions [8].

Assessment of the participants' physical condition (body resistance to adverse external factors) and their adaptive potential (intensity of the adaptive reactions) [8]. A. G. Gorelkin and B. B. Pinkhasov's formulas [9] enabled calculation of the rate of aging and biological age of all the participants.

Microsoft Excel and Statistica 6.0 were used to statistically process the data. Student's t-test allowed determining the significance of the differences. The differences were considered significant at $\mathrm{p}<0.05$. Spearman's rank correlation coefficient was used to determine the relationship between the indicators.

\section{RESULTS}

Anthropometric measurements showed that female professors had a body weight within the normal range 2.2 times more often (63.2\% versus 28.0\%, $p<0.001)$. Excess body weight was registered in $59.7 \%$ of men and $3.4 \%$ of women, moderate obesity - in $12.2 \%$ of male participants and $33.3 \%$ of their female counterparts ( $p<0.001$ ). Waist circumference higher than normal according to the current WHO standards was found in 93.1-95.1\% of the participants, which indicates they are developing abdominal obesity. At the time of measurements, $24.1 \%$ of women and $36.6 \%$ of men had the blood pressure above 140/90. That said, almost all male professors stated they were diagnosed with hypertension and are observing the therapeutic instructions given by their doctors earlier. However, these participants have also admitted that they had not been through a routine examination for a long time and probably the mentioned instructions require adjustments.

In $67.1 \%$ of men and $22.9 \%$ of women, the registered level of physical condition was low $(p<0.001)$. A high level thereof $(28.7 \%, p<0.001)$ was peculiar to female participants only.

The assessment of the body's adaptive potential has reveled that not a single participant of the study has sufficient functional capabilities to adapt to the changing environmental factors (satisfactory adaptation). Every third woman and every second man had their adaptation capabilities assessed as unsatisfactory $(p<0.05)$.

The normal rate of aging was observed in $25.3 \%$ of women and $7.3 \%$ of men $(p<0.05)$, while 16.1 and $12.1 \%$, 
respectively, were aging at an accelerated rate. However, $58.6 \%$ of female participants and $80.5 \%$ of their male counterparts are aging at a slow rate $(p<0.01)$. As for the biological and chronological age correlation, $68.9 \%$ of women and $87.8 \%$ of men were biologically younger than chronologically $(p<0.01)$. We also assessed the relations between the body weight and the aging rate coefficient values. The correlation ratio was 0.900 for men and 0.875 for women, which signals of a strong direct correlation between the body weight and the rate at which the body ages, this rate registered higher in female professors.

\section{DISCUSSION OF THE RESULTS}

Analysis of the data obtained showed that gender affects values of most indicators significantly. In this context, body mass index is the one that should be considered before all the other. Throughout the world, overweight and obesity are among the significant risk factors raising the rate of mortality associated with noncommunicable chronic diseases [3]. In our study, $72.0 \%$ of male participants and $36.8 \%$ of female participants were registered as overweight and/or obese. In their publications, Martynchik A. N. et al. [5] note that in the recent years male obesity has been diagnosed significantly more often, female obesity less so. At the same time, female professors of pre-retirement and retirement age suffer from obesity twice as often as their male colleagues, which is consistent with the general Russian population data - 30.8\% versus $26.9 \%, p<0.001$ [7]. Waist circumference is a unique marker of adipose tissue distribution and an indicator of high cardiometabolic risk [10]. According to the WHO [11], waist circumference above $\geq 94 \mathrm{~cm}$ in men and $\geq 80 \mathrm{~cm}$ in women means a risk of developing arterial hypertension, coronary heart disease and other diseases of the cardiovascular system. In our study, $95.1 \%$ of men and $93.1 \%$ of women had their WC measuring more than the stated values, i.e., they suffered from abdominal obesity. We have also discovered a strong direct correlation between body weight and body aging rate, and it was found to be higher in women, which, in our opinion, may be associated with a higher prevalence of obesity among them.

The gender-specific differences in blood pressure levels that we identified confirm the data of a number of studies on the prevalence of this factor among male individuals, even when they take AHD [6, 10]. V. Malinauskienë et al. [12] proved there is a relationship between work-related stress among professors and CVD. The results of our survey showed that more than $70 \%$ of the respondents were diagnosed with hypertension, and "coronary heart disease" was the diagnosis announced to every third man and every seventh woman $(p<0.05)$. At the same time, only $28.0 \%$ of male respondents suffering a chronic pathology take medications as prescribed by their doctors to support the cardiovascular system, while all female participants never fail to strictly follow the therapeutic instructions.

In terms of physical condition and adaptive potential, male professors demonstrated significantly lower functional capabilities compared to their female counterparts.

\section{CONCLUSIONS}

We have discovered significant gender-dependent differences in a number of values of morpho-functional status indicators (body weight, waist circumference, physical condition, etc.) that signal of the risk of development of such diseases as arterial hypertension, coronary heart disease and other diseases of the cardiovascular system. At the same time, the overwhelming majority of male professors with a chronic cardiovascular pathology do not follow instructions given by their doctors or have not had them adjusted for a long time. However, female participants presented significantly more cases of obesity, which explains the revealed differences in the rate of aging that was higher among women.

Thus, the results of our study support the need for a system of measures aimed at preservation of health and improvement of working efficiency of elderly medical university professors, such a system promoting rational nutrition, physical activity and timely prevention of development of chronic pathologies.

\section{References}

1. Zinkina JV, Korotayev AV. The gender gap in life expectancy: a review of genetic, social, and value factors. Demografic Review. 2021; 8(1): 106-126.

2. Pugach V.F. The age of teachers in Russian universities: what is the problem? Sociology of education. 2017; 1: 47-55. Russian.

3. Gazizov RR, Shulaev AV, Khayrullina LM. Medical and social aspects of the health status of scientific and pedagogical workers of educational institutions. The Russian journal of preventive medicine. 2020; 23(2): 13-18. Russian.

4. Smagulov NK, Evnevich AM, Adilbekova AA. Influence of educational process on the health of teachers of the medical university. Russian journal of occupational health and industrial ecology. 2019; 9: 756-757. Russian.

5. Martinchik AN, Baturin AK, Keshabyants EE, Peskova EV. Gender and age characteristics and the trends in prevalence of obesity in the adult population in Russia during the 1994-2012 period. Voprosy pitaniya. 2015; 84(3): 50-57. Russian.

6. Rotar OP, Tolkunova KM, Mevsha OV, Nedbaikin AM. Screening blood pressure measurement in the Russian population (the results of the MMM17 activity). Arterialnaya gipertenziya. 2018; 24(4): 448-458. Russian.
7. Balanova YuA, Shalnova SA, Deev AD, Imaeva AE, Kontsevaya AV, Muromtseva GA, Kapustina AV, Evstifeeva SE, Drapkina OM. Obesity in russianpopulation - prevalence and association with the non-communicable diseases risk factors. Russian Journal of Cardiology. 2018; (6): 123-130. Russian.

8. Nikiforov GS. Workshop on health psychology. SPb .: Piter; 2006; 461 p. Russian.

9. Derevtsova SN, Romanenko AA, Tichonova NV, Medvedeva NN. Body mass index and aging rate indicators physical state of elderly women. Medical news of North Caucasus. 2016; 11(3): 414-417. Russian.

10. Klein Samuel, Allisson David B., Heymsfield Steven B., Kelley David E., Leibel Rudolph L. Waist Circumference and Cardiometabolic Risk. Arterial'naya gipertenziya. 2007; 13(3): -194.

11. Poetapnyy podkhod VOZ (STEPS) k epidnadzoru faktorov riska khronicheskikh zabolevaniy. Departament khronicheskikh bolezney i ukrepleniya zdorov'ya [Internet]. VOZ, Zheneva, 2017. Available from: https://www.who.int/ncds/surveillance/steps/ manual/en/

12. Romualdas K. Malinauskas, Vilija V. Malinauskiene, Vytautas P. Gudonis. Emotional Intelligence Features of Future Teachers of Physical Education. European Researcher. 2013; 43(3): 602-605. 


\section{Литература}

1. Зинькина Ю.В., Коротаев А.В. Разрыв ожидаемой продолжительности жизни мужчин и женщин: обзор генетических, социальных и ценностных факторов. Демографическое обозрение. 2021; 8 (1): 106-126.

2. Пугач В.Ф. Возраст преподавателей в Российских ВУЗах: в чем проблема? Социология образования. 2017; 1: 47-55.

3. Газизов Р.Р., Шулаев А.В., Хайруллина Л.М. Медикосоциальные аспекты состояния здоровья научнопедагогических работников образовательных учреждений. Профилактическая медицина. 2020; 23(2): 13-18.

4. Смагулов Н.К., Евневич А.М., Адилбекова А.А. Влияние образовательного процесса на здоровье преподавателей медицинского университета. Медицина труда и промышленная экология. 2019; 9: 756-757.

5. Мартинчик А.Н., Батурин А.К., Кешабянц Э.Э., Пескова Е.В. Гендерные и возрастные особенности и тенденции распространения ожирения среди взрослого населения России в 1994-2012 гг. Вопросы питания. 2015; 84(3): 50-57.

6. Ротарь О.П., Толкунова К.М., Мевша О.В., Недбайкин А.М. Скрининговое измерение артериального давления в российской популяции (результаты акции МММ17). Артериальная гипертензия. 2018; 24(4): 448-458.

7. Баланова Ю.А., Шальнова С.А., Деев А.Д., Имаева А.Э., Концевая А.В., Муромцева Г.А., Капустина А.В.,
Евстифеева С.Е., Драпкина О. М Ожирение в российской популяции - распространенность и ассоциации с факторами риска хронических неинфекционных заболеваний. Российский кардиологический журнал. 2018; (6): 123-130.

8. Никифоров Г.С. Практикум по психологии здоровья. СПб.: Питер; 2006; 461 с.

9. Деревцова С.Н., Романенко А.А., Тихонова Н.В., Медведева Н.Н. Индекс массы тела и коэффициент скорости старения в оценке физического статуса женщин пожилого возраста. Медицинский Вестник Северного Кавказа. 2016; 11(3): 414-417.

10. Klein Samuel, Allisson David B., Heymsfield Steven B., Kelley David E., Leibel Rudolph L. Окружность талии и кардиометаболический риск. Артериальная гипертензия. 2007; 13(3): 189-194.

11. Поэтапный подход ВОЗ (STEPS) к эпиднадзору факторов риска хронических заболеваний. Департамент хронических болезней и укрепления здоровья [Электронный ресурс]. ВОЗ, Женева, 2017. Режим доступа: https://www.who.int/ncds/ surveillance/steps/manual/en/

12. Romualdas K. Malinauskas, Vilija V. Malinauskiene, Vytautas P. Gudonis. Emotional Intelligence Features of Future Teachers of Physical Education. European Researcher. 2013; 43(3): 602-605. 